native area of the Northern Transvaal when nineteen natives of the Barolong tribe were killed. The report states: "About $3 \mathrm{in}$. of rain fell in a few minutes, and then came the hail, which consisted of jagged lumps of ice. In 30 minutes the hail was lying everywhere to a depth of $3 \mathrm{ft}$., and in some cases the dead natives had to be dug out of it. There were many cattle killed, which the natives afterwards dragged away on slejghs. Whole crops were obliterated, and there are said to be over 1,000 native families afflicted in the area".

\section{Ancient Shafts at Ipswich}

Messrs. Bolmon's brickfield at Ipswich, already well known to archæologists as a valuable source of evidence bearing on the cultures of the Old Stone Age, recently has been the site of another remarkable discovery, unique in the annals of British archæology, but not yet explained with certainty. Three shafts of a remarkable character and of a previously un. known type have been exposed, of which two have been partially cleared by Mr. J. Reid Moir. Of these, the first, according to a report in The Times of January 29, was cylindrical in shape, and approximately three feet ten inches in external diameter, with walls of puddled clay nine inches thick. It was followed through the London clay into the Eocene sands; but neither here nor in the second shaft did excavation reach the bottom. Work in the second shaft had to be abandoned at a depth of seventy feet owing to the presence of water. This shaft was larger than the first, being some six feet in diameter, and more complex in its filling, at least down to a depth of eighteen feet. It had as a central core a pillar of puddled clay, with two walls of white clay between it and the outer wall. In both shafts at a considerable depth the clay walls coalesced to form a species of basin or false bottom, sealing the lower part of each shaft. Finds of archæological significance were scanty. Fragments of Roman brick, two pieces of silver sheeting, such as might have formed part of the cover of a casket, and a fragment of polished marble, which might have been part of the casket itself, when taken in conjunction with the proximity of a Roman burial ground and the later Roman Castle Hill villa, have afforded a basis for the suggestion that these may be Roman burial shafts, such as the Puits funeraires of France, or the late Roman shafts leading to burial chambers of Cyprus.

\section{Journal of the History of Science}

A NEW token of the growing interest in the history of science, is provided by the appearance of the first number of "a quarterly review of the history of science since the Renaissance", under the title of Annals of Science. This new periodical is edited jointly by Dr. D. MeKie of University College, London, Dr. Harcourt Brown, of Washington University, St. Louis, U.S.A., and Mr. H. W. Robinson, librarian of the Royal Society. It aims at dealing with the development of modern science in much the same way as Isis deals with the science of the earlier eras, and to encourage the study of the life and work of the great masters and makers of science. "The personal note in the history of Science," adds the editorial, "is, indeed, just as interesting and just as valuable as the personal note in the history of Literature or the Arts. And there remain many inviting unworked corners in the field of scientific biography which still await the attention of the interested student and will amply reward his spade-work". The first issue runs to 113 pages, and includes seven articles and two signed book-reviews.

Prof. E. N. da C. Andrade describes an attempt of John Wilkins, Warden of Wadham, Bishop of Chester, and originator of the Royal Society, to found a universal language, based upon a system of signs, or characters. There are articles on early nautical charts; the history of the Chile nitrate industry; Descartes and Henry More on the beastmachine-a translation of their correspondence pertaining to animal automatism; and the detection and estimation of electric charges in the eighteenth century. Prof. T. S. Patterson contributes an interesting identification of a certain Richard Boyle, who was admitted among the original members of the Royal Society. The closing contribution, by Dr. McKie, describes a MS. set of notes of Joseph Black's chemical lectures, made by Thomas Cochrane in 1767-68; these throw some interesting light on Black's chemical views at this early period in his career. Two new sketches of Black at his lecture table, by Cochrane, are reproduced. The journal is well printed and illustrated on a page of satisfying dimensions, with generous margins. Judging from the first issue, it will make a strong appeal to all who are interested in the history of science. It is published by Messrs. Taylor and Francis, Red Lion Court, Fleet Street, London, E.C.4, and the annual subseription is $£ 1$, including postage.

\section{British Industries Fair}

The British Industries Fair, 1936, will be held at Olympia and the White City, London, and at Birmingham, on February 17-28. The general exhibits will be seen at Olympia, the furniture and textiles section at the White City and the engineering and hardware section at Birmingham. There will be no less than twenty-four miles of exhibits, of which London's stand frontage will be $12 \frac{1}{2}$ miles and Birmingham's $11 \frac{1}{2}$ miles. The Overseas catalogue recently issued contains a classified list of exhibitors which alone occupies 170 pages, and the key-parts of the catalogue are printed in nine languages. The organisers are able again to say, as they have said in each preceding year, that it will be a record. breaking Fair. The exhibitors number 1,421, London contributing most of them-775. Other cities and districts sending exhibitors to the Fair are, following the order of their contributions: Birmingham, the Potteries, Manchester, Sheffield, High Wycombe, Nottingham, Leeds and Liverpool. Seven sections are larger than last year, and the display of furniture at the White City will be the largest in the history

(Continued on p. 229.) 